\title{
Girl Power's Last Chance? \\ Tavi Gevinson, Feminism, and Popular Media Culture
}

\begin{abstract}
:
This paper focuses on Tavi Gevinson, the teenage fashion blogger-turned-editor in chief of the online magazine Rookie, as a case study with which to interrogate the production and circulation of feminist politics within a "post girl power" era.

Drawing on theories of performativity, I employ a discursive and ideological textual analysis of Gevinson's self-produced media and media coverage to map how Gevinson uses the opportunities afforded by digital media to rearticulate narratives of "girl power" and perform a feminist girlhood subjectivity that makes feminism accessible to her many readers. While I argue that Gevinson's ability to do so is positive and demonstrates the porous nature of postfeminist media culture, I also suggest that we must be critical of the ways in which Gevinson's feminism functions as part of her self brand that reproduces feminism as white, middle-class, and "hip." Thus, I conclude by questioning a larger cultural trend towards the branding of feminism and advocating the need for an intersectional approach to understanding the resurgence of feminism within contemporary popular media culture.
\end{abstract}

\section{Author Bio:}

Jessalynn Keller is a Lecturer in New Media at Middlesex University London, having completed her Ph.D. at the University of Texas at Austin in 2013. Her book, Girls' Feminist Blogging in a Postfeminist Age is an ethnographic study of U.S.-based feminist girl bloggers and is forthcoming from Routledge in late 2015. Jessalynn has also published work in Feminist Media Studies; Information, Communication, and Society; Women's Studies International Forum, and in several edited collections. Her newest project funded by the Arts and Humanities Research Council (UK), examines how digital feminist activism is challenging rape culture across online and offline spaces.

\author{
Author Contact: \\ Dr. Jessalynn Keller \\ Department of Media \\ Middlesex University London \\ Jessalynn.keller@gmail.com
}

In a September 2012 article in the Canadian newspaper The Globe and Mail, columnist Katrina Onstad provocatively raised the question: "Is Tavi Gevinson girl power's last chance?" Onstad suggests that Gevinson, the Chicago-based teenage founder and editor-in-chief of the online girls' magazine Rookie (rookiemag.com) is 
reviving a feminist girl culture originally cultivated in the early 1990s through the feminist punk subculture, riot grrrl. Gevinson's public identification as a feminist, promotion of girls' communities, and progressive Rookie articles that make feminism relevant to teenage girls mirror riot grrrl practices and are a significant deviation from the apolitical media for girls primarily created by adults. Thus, Onstad is partially right in suggesting that Gevinson represents a resurgence of the cultural politics of an era before she was born and symbolizes a return to riot grrrl politics as a way to resist postfeminist media culture.

Yet, unlike the riot grrrls, many of whom shunned mainstream media interest and attempted to avoid celebrity status, Gevinson has courted media attention since she gained public attention as an eleven-year-old fashion blogger and has been featured in publications ranging from New York Magazine to Adweek to Teen Vogue. Gevinson has been an influential force within girls' culture for several years as she transitioned from quirky tween fashion blogger to the media mogul she is today, presiding over the Rookie brand which includes a website and two printed books. In this sense, Gevinson is indicative of what Anita Harris (2004) calls the "can-do girl," a girl who is independent, self-made and ambitious, demonstrating a willingness to participate in the capitalist marketplace as both a consumer and eventually, worker. The can-do girl is a girl who has embraced "girl power" and has benefitted from its incorporation into popular culture as a hegemonic discourse within postfeminist media culture. Thus, this "post-girl power" era is one where girls are not only "expected/demanded to be fully self-actualized neoliberal subjects" but also one 
where new opportunities for agency and resistance emerge (Gonick, Renold, Ringrose and Weems 2009, 2).

Gevinson represents a notable yet under-analyzed tension between the public performance of feminist politics that promotes the formation of girls' communities, political activism, and cultural production as necessary activities for girls and a postfeminist media culture where self-branding, circulated visibility, and achieving celebrity is normalized for girls (Banet-Weiser 2012; Hopkins 2002). While feminist scholars have produced productive analyses of postfeminist media culture (Gill 2007; McRobbie 2009; Negra 2009), and the "girl power" discourse that informs this media targeting girls (Zaslow 2009; Currie, Kelly, and Pomerantz 2009; Hains 2012), few researchers have grappled with the ways in which girls themselves are engaging in feminist politics through postfeminist media culture.

In this paper I begin to address this oversight by exploring the tensions and contradictions between feminist politics and postfeminist media culture using Gevinson as a productive case study to consider the following questions: How has Gevinson rearticulated "girl power" as practiced by riot grrrls within Rookie's digital media culture? How has this strategy functioned simultaneously as a way to create opportunities within postfeminist media culture to perform alternative feminist girlhood subjectivities and to generate a lucrative self-brand for Gevinson? What might these actions suggest about the cultural narrative of "girl power" today, amidst a cultural context where girlhood remains a highly circulated commodity within digital media spaces? 
I address these questions through a discursive and ideological analysis of Gevinson's self-produced media, as well as media coverage of the blogger; focusing primarily on the two-year period between September 2011 and September 2013. I situate my analysis within a body of cultural studies and girls' studies scholarship that examines postfeminism, neoliberalism, and brand cultures from a feminist perspective. I draw on theories of performativity to interrogate the ways in which Gevinson's media persona must be viewed not as an "authentic" presentation of self, but a mediated performance situated within a culture that demands girls and young women to self-brand (Banet-Weiser 2012).

I argue that Gevinson uses the opportunities afforded by digital media production to perform and circulate alternative girlhood subjectivities that draw on discourses of girl power articulated by riot grrrl, including those that incorporate feminism, friendship, and politics as a part of contemporary girlhood identities. This is a significant accomplishment, as it not only challenges some of the postfeminist discourses about girlhood, such as the figure of the "universal mean girl" (Ringrose 2012), but also serves to introduce feminist politics to Rookie's wide readership. Thus, Gevinson demonstrates the somewhat porous nature of postfeminist media culture, whereby feminist politics can and do appear within popular media texts.

Gevinson's performance as a "media savvy interactive subject" (Banet-Weiser 2012) mediated through both Rookie and her extensive popular press coverage means that her feminist politics are often articulated in relation to her self-brand, which is based upon a "subcultural capital" (Thornton 1996) that is hip, urban, and pop culture-savvy. Because Gevinson's feminism is bound tightly within her self- 
brand, it is translated as something that is primarily white, middle class, and "cool," complicating the collective solidarity amongst girls Rookie attempts to cultivate. This paper then raises important questions about the possibilities for a diversity of girls to participate in feminist girls' culture such as the one generated by Rookie and attempts to intervene into the ongoing public debate about the production, mainstreaming and branding of a "hip" feminism within a postfeminist media culture (Alvaraz 2013).

\section{The Tavi Brand: Digital Media, Entrepreneurship and Feminism}

In an April 2013 cover story in Adweek, the industry magazine describes Gevinson as a "media mogul... expanding her empire" (Bazillian 2013), pointing to her successful navigation of the digital media landscape. Gevinson's biography is an impressive list of accomplishments that spans media, fashion, publishing, film and theater industries. Gevinson gained attention as a tween fashion blogger in 2009 after her blog The Style Rookie (http://www.thestylerookie.com/) captivated fashion industry insiders with its creative photography and witty commentary. Since then she has penned articles for fashion bible Harper's Bazaar, sat in the front row of global fashion week shows, modeled alongside Cyndi Lauper for Japanese clothing chain Uniqlo, and has spoken at prominent conferences, such as TedxTeen 2012.

In September 2011 Gevinson launched an online magazine for teenage girls titled Rookie, which garnered over one million page views less than a week after its launch (Goodman 2013). Gevinson capitalized on the success of Rookie by 
embarking on a cross-country Rookie Road Trip in summer 2012 to meet her readers and to promote the launch of Rookie Yearbook One, a printed book of selected posts from Rookie's first year. Her second edited book, Rookie Yearbook Two, was published in September 2013 -- only a few weeks before the release of Enough Said, in which Gevinson's acting was critically acclaimed. In summer 2014 the recent high school graduate starred in the play This Is Our Youth in Chicago, which moved to New York's Broadway in September for a four-month run, an opportunity that led to media coverage in $W$, Rolling Stone, and The New Yorker.

Gevinson's successful career points to her ability to understand a media culture characterized by converged industries, online technologies, and rapid change (Jenkins 2006). This media culture requires one to be a "media savvy interactive subject," which Sarah Banet-Weiser (2012) describes as someone who produces media content that circulates across media platforms, one who " 'finds' a self and broadcasts that self, through those spaces that authorize and encourage user activity" (56). Gevinson's media products hinge on this practice that BanetWeiser describes: From her active use of Twitter to communicate with over 200,000 followers to her reliance on reader feedback on Rookie, Gevinson embraces the interactivity that new media platforms afford. In doing so Gevinson is able to present herself as a peer and confidante to her many fans, an aspect of her self brand that she's mobilized to create girl communities through initiatives such as the Rookie Road Trip.

It is worth considering the "finding and broadcasting of a self" that BanetWeiser describes, a practice that I'm referring to as self-branding. Hearn (2008) 
defines self-branding as the "self-conscious construction of a meta-narrative and meta-image of self through the use of cultural meanings and images drawn from the narrative and visual codes of the mainstream culture industries" (198). This practice, according to Hearn (2010), is a function of the image economy where attention and fame is capital, and may include strategies that range from circulating a witty tweet to developing a signature fashion style.

While scholars most often discuss self-branding in relation to shifting forms of labour within neoliberal economies, I am interested in how self-branding functions as a gendered practice that correlates to the demands of postfeminist femininity. Rosalind Gill (2007) and Angela McRobbie (2009) have theorized postfeminism as a hegemonic and neoliberal cultural sensibility that repudiates feminism as a collective political project while celebrating the empowerment of individual girls and women through apolitical and capitalist activities, including the consumption of fashion and beauty products, the maintenance of disciplined bodies, and productivity through entrepreneurship. It is this last point that is important to consider in relation to Gevinson.

Postfeminism privileges entrepreneurship as a way for girls and young women to participate in social life, confirming and normalizing the neoliberal values of individualism, self-reliance, and innovation (Banet-Weiser 2012; McRobbie 2009; Harris 2004). Harris argues, "The girl entrepreneur is the ultimate self-inventing young woman who represents a fantasy of achievement accomplished by good ideas, hard work, and self-confidence" $(2004,74)$. Often, the girl entrepreneur is selling herself, engaging in self-disclosure as a mode of revealing a "true self" that 
becomes publicly legible, celebrated, and even monetized (Banet-Weiser 2012). We may understand the girl entrepreneur as an entrepreneur of the individual postfeminist self who mobilizes self-branding as a technique to gain public attention, reputation, and even profit (Hearn 2010; Banet-Weiser 2012). Based upon this framework, we can understand self-branding as privileging the individual, aligning with the focus on individualism inherent in both postfeminist and neoliberal discourses.

While I discuss Gevinson in relation to this cultural moment where girls are encouraged to be entrepreneurs of the self, I want to emphasize that I am not arguing for understanding Gevinson's mediated persona as indicative of an inherent, authentic self - the "real" Gevinson. Instead, I draw on theories of performativity to analyze Gevinson's actions, including her self-branding, as indicative of repetitive mediated performances that allow us to come to know Gevinson as a subject (Butler 1990). In doing so I employ a Butlerian conception of performativity that posits it as the "reiterative power of discourse to produce the phenomena that it regulates and constrains" (Butler 1993). This framework is useful, as it recognizes the discursive limits in which Gevinson operates, yet does not foreclose the possibility of her agency in creating social change.

Gevinson's experience as a fashion blogger has informed her self-brand as eclectic, creative, and fashion forward. We can see this image in recent high fashion shoots, such as an August 2014 photo in $W$, a seminal fashion industry publication. Gevinson's intelligent commentary on popular culture, circulated on Rookie as well as on her Twitter and Tumblr accounts, portray her as witty and well read. Yet, as 
I've mentioned, she also performs as a best friend, "one of the girls" that publicly shares photos from her Sweet 16 and meets her readers for ice cream. Gevinson can thus be understood as performing "subcultural capital," which Sarah Thornton (1996) describes as a kind of "hipness" that confers a recognized social status on its owner. She explains subcultural capital as being, "objectified in the form of fashionable haircuts and well-assembled record collections [and] embodied in the form of being 'in the know' " (11-12). Thornton contends that subcultural capital appears natural to certain people, bestowing an authenticity on those who are able to successfully perform such capital, including Gevinson. Unlike the cultural outputs of celebrity girl actresses or pop singers which can appear manufactured, Gevinson's posted music recommendations consisting of obscure 1990s riot grrrl bands and musings on New York Fashion Week appear authentic, further establishing Gevinson's brand as a connoisseur of cool that seemingly operates outside of, yet in conversation with, the commercial culture industries.

Gevinson's self-branding has been instrumental to her creation of Rookie and her overall success as a digital entrepreneur. Unlike the examples of postfeminist self-branding discussed by feminist scholars (Banet-Weiser 2012; Senft 2008; Dobson 2008), Gevinson's self-brand, which includes her identification as a feminist, complicates the existing analysis of the digital self-brand as a solely postfeminist, entrepreneurial pursuit devoid of political subjectivity. For example, in a spring 2012 interview for the PBS Makers series Gevinson is identified in an accompanying caption as a "Fashion Blogger \& Feminist," highlighting feminist politics as a central aspect of her identity performance. Gevinson has been vocal about being a feminist 
since mid-2010, often framing her development of Rookie as a response to a lack of feminist media for girls (PBS 2012).

By identifying publicly as a feminist Gevinson performs a political subjectivity, challenging hegemonic postfeminist discourses that suggest girls are apolitical and not interested in feminism, and creating discursive space for feminist politics within a postfeminist media culture. I have argued elsewhere that for girls merely publicly identifying as a feminist functions as a resistant practice in that it grants girls a speaking position from which they can critique hegemonic postfeminist femininity and "offers girls a political subjectivity to make sense of the world that few other normative girlhood identities offer" (Keller 2013, 96). Online spaces have been significant to this process, providing anonymous space to "experiment" (Keller 2013; 2012) with feminist identities and affording girls a chance to connect with other feminist girls and women. Gevinson's performance of a feminist identity as part of her self-brand can be viewed as a challenge to postfeminist girlhood subjectivities and may encourage her girl fans to explore feminism for themselves.

\section{Riot Grrrl in Rookie: (Feminist) Politics and Promotional Skin}

As Onstad (2012) emphasizes, Gevinson's feminist politics are heavily influenced by the cultural politics of riot grrrl, a girl-centered punk subculture that began in the U.S. in the early 1990s. There are two significant aspects of riot grrrl that are relevant to my discussion of Gevinson and Rookie. First, riot grrrls practiced feminism from a girl subjectivity which they dubbed "girl power,"1 not only rewriting feminism to address the concerns of girls such as beauty standards, sexual 
abuse and pressure to be "perfect," but "reinventing girlhood and girls' culture for a new millennium" (Kearney 2006, 65). In this sense, riot grrrl was accessible to (some) girls and young women in ways that mainstream adult-produced feminism was not.

Second, the riot grrrl community was sustained through girls' self-produced media products, including zines, music, and crafts. Thus, riot grrrls not only encouraged girls to be media producers, but motivated girls to create alternative representations of girlhood that challenged those created by the commercial culture industries (Kearney 2006). Based upon these two characteristics of riot grrrl we can see why the movement was likely appealing to Gevinson as a girl cultural producer who was often not taken seriously as a fashion blogger due to both her age and gender (Keller 2013). I have argued elsewhere that Gevinson's turn to feminism may have been precipitated by the lack of respect she received by some fashion industry insiders, as riot grrrl-inspired feminism provided her the language to make sense of her experience (Keller 2013).

As a result of Gevinson publicly expressing her interest in riot grrrl on her blog as well as in interviews with the press, Gevinson herself became representative of the next generation of riot grrrl within mainstream media. This is evident in Onstad's suggestion that Gevinson represents "girl power's last chance" and in articles such as “The New Riot Grrrls?” (Bastow 2012), which link Gevinson's politics, media production practices and style with the movement. Riot grrrl, in this sense, became a part of the way in which Gevinson performs her identity, and upon circulation throughout her various social media platforms, part of her self-brand. 
Gevinson's posted discussions of her friendship with prominent riot grrrl Kathleen Hanna, Polaroid's of herself wearing riot grrrl-inspired baby barrettes, and scrawled playlists with riot grrrl bands like 7 Year Bitch and L7 work to generate a symbolic self that, in the words of Alison Hearn (2012) function as a "promotional skin" that associates Gevinson with the politics, affects, and aesthetics of 1990s "girl power." Gevinson often includes information about riot grrrl in Rookie, including recent interviews with riot grrrls Kathleen Hanna and Carrie Brownstein, articles on how to make a zine, and fashion spreads inspired by Hole's 1994 music video for the song "Miss World." By including these types of stories in Rookie Gevinson introduces riot grrrl and feminism to her girl readers who may not be familiar with either, providing a history for feminism that encourages girls to understand their own struggles as part of a lengthy history of feminist activism.

Beyond merely writing about riot grrrl, Gevinson applies riot grrrl politics to her personal life and writes about it in Rookie. For example, in a September 2011 post called "First Encounters with the Male Gaze" Gevinson discusses how sexual harassment permeates the high school environment and how girls feel when they first witness others noticing their changing bodies. She writes of her male peers who engage in sexual harassment:

I want these guys to know that they're able to be so cavalier because they don't hear unsolicited opinions on their bodies and alleged sex lives all the time.... because your transition into puberty didn't include the same kinds of ridiculous beauty expectations, and then unsolicited evaluations of how well you measured up. 
Gevinson's attention to girls' experiences with sexual harassment within high school is likely informed by her familiarity with riot grrrl's emphasis on feminism as it applies to girls' everyday lives, as well as their attention to sexual harassment. By publishing a piece such as this one Gevinson creates the discursive space for girls to publicly discuss this too-common experience, a strategy also used by riot grrrls. Indeed, this article received over 100 comments, many from girls and women who described their own experiences with sexual harassment. The exchanges on the comment section also function as a significant example of intergenerational feminism, as teenage girls are actively participating in feminist conversation with women who have identified themselves as in their twenties, thirties, and forties; an experience which challenges the logic of "disarticulation" (McRobbie 2009) within postfeminist discourses. It also points to the potential of online spaces to serve as productive places for intergenerational feminist discussions, even within a postfeminist media culture.

Yet despite the opportunities for new discursive online spaces and connections amongst girls and between feminist girls and women, Gevinson's rearticulation of riot grrrl within a postfeminist media culture risks replicating the privileging of the "can do" girl's (Harris 2004) public visibility and experiences within the public sphere; excluding girls who do not have the race or class privilege to occupy this idealized position. While scholars have noted the ways in which many girls of color and those from lower socioeconomic status were excluded from riot grrrl twenty years ago (Kearney 2006), there has been little commentary on the ways in which Gevinson's race and class privilege allow her to perform identity - 
including a riot grrrl influenced feminist identity - in ways that other girls cannot do easily (Wald 1997; Kearney 2006).

For example, some girls of color have argued that Rookie fails at intersectionality, an important critique that has been noticeably absent from mainstream press coverage of the website. In a December 2012 post on the Rude Girl Magazine Tumblr (http://rudegirlmag.tumblr.com/), Bre describes how she began Rude Girl because she felt excluded as a girl of color from the discussions that were happening on Rookie and was particularly upset with the ways in which the website appropriates the cultures of women of color. While Rookie did publish an article addressing why cultural appropriation is problematic ("Something Borrowed") which received over 400 comments, Bre argues that the discussion is "offensive" in light of Rookie's own use of cultural appropriation as a way to create supposedly hip style suggestions, such as a flower crown hair style worn by Frida Kahlo ("Flowery and Frida-esque") or clothing pairings to mimic looks from the Harlem Renaissance ("Secret Style Icon: Ladies of the Harlem Renaissance"). Rookie employs a diversity of writers on staff and attempts inclusivity by publishing stories such as a piece on being bi-racial ("On Containing Multitudes"), coming out as gay ("The Safety Closet"), and identifying as transgendered ("My Kind of Guy"). However, Bre's comments point to the difficulty in separating Rookie from Gevinson's own self-brand, an image created through her ability to access alternative feminist cultures such as riot grrrl and perform these identities publicly; a performance arguably made possible due to her upper middle-classness, whiteness, and American-ness, as well as her conventional physical beauty. 
Gevinson's feminist politics are articulated from a position of privilege to which many girls may be unable to relate. To be clear: I am not criticizing Gevinson nor am I suggesting that her feminist politics are unimportant. I am instead arguing that we must be better attuned to how the practice of self-branding may limit which girls are able to perform feminist identities within a post-girl power context and who is able to identify with such alternative girlhood subjectivities.

\section{Road Tripping: (Branded) Communities, Girls' Friendships, and Public Space}

In summer 2012, Gevinson embarked on a 16-city U.S. road trip with several other Rookie staffers, meeting readers in local cafes, parks, and record shops. While described by Gevinson in terms of the pursuit of leisure and friendship, the road trip also functioned as promotion for Rookie, the upcoming release of Rookie Yearbook One, and publicity for Gevinson herself, deemed an "oracle of girl world" by the New York Times (Schulman 2012). The trip also forged an alliance between Rookie and Urban Outfitters through the company's sponsorship of the trip, creating what Sarah Banet-Weiser calls a "brand culture" whereby "consumers produce identity, community, emotional attachments, affective practices, and relationships both with the brand and with each other" $(2012,46)$.

Known as a global brand that sells mass-produced clothing, accessories, and housewares that incorporate retro, vintage and bohemian trends, it is unsurprising that Urban Outfitters would court a partnership with Gevinson. Her days as a fashion blogger established Gevinson as a style icon whom imaginatively mixes high fashion items with vintage finds, homemade goods, and high street staples; a DIY 
(do-it-yourself) approach to fashion that Urban Outfitters imitates through their corporate branding. By sponsoring the Rookie road trip Gevinson lends the company an air of authenticity and alternative hipness to their brand, resulting in new promotional opportunities for Urban Outfitters. For example, the company produced a "Rookie Road Trip Essentials" webpage where various fashion goods were marketed to girls as "must haves" for their participation in the scheduled meet-ups. The road trip then became a semi-commercialized event where girls were encouraged, at least by Urban Outfitters, to consume fashion and beauty products as a way to participate in social life, a common discourse within postfeminist media culture (Harris 2004).

But while Gevinson's decision to partner Rookie with Urban Outfitters seems antithetical to her DIY riot grrrl politics and creative style, I am suggesting that this partnership illustrates one tenant of this paper, namely, that in a post girl power media culture these types of neoliberal branding strategies are normalized; they are merely part of the logic of a converged media culture that demands girls like Gevinson negotiate their feminist politics with an all-encompassing consumer culture. Unlike the riot grrrls' shunning of the commercial culture industries, Gevinson operates in tandem with them, granting Urban Outfitters access to her audience, while strategically using their resources to not only make the road trip possible, but also accessible to her girl readers who may shop at one of the company's many stores. Thus, while recognizing the Rookie road trip as producing branded spaces and therefore not divorced from the late capitalist logic that informs such spaces, I am interested in how Gevinson has nonetheless manipulated this 
opportunity to complicate postfeminist discourses on girls' friendships and promote girls' communities as generative of feminist social change.

One of the most interesting aspects of the Rookie road trip was its structure: informal gatherings at local favorite public places suggested by Rookie readers. While many girls in the United States have considerably more personal freedom to occupy public space than previous generations of girls, we must still consider what it means for a group of girls to physically occupy these spaces as consumers in some cases, but also as cultural producers, friends, and girls. While scholars have usefully theorized neoliberalism as requiring a reprivatizing of girls' politics and simultaneously publicizing girls' private lives (Harris 2004), the Rookie meet-ups can be seen as potentially challenging this trend by re-publicizing girls' politics through these gatherings, occupying and even "taking over" public space with numbers that have reached close to two hundred at one meet-up.

As adult researchers we may overlook how the act of physically joining these gatherings point to an element of resistance amongst Gevinson's fans. For example, Gevinson tells Bitch Magazine how a homeschooled Philadelphia girl "had to sneak out of the house to go to our event, which was in the middle of the day, and had to wear her brother's shoes because she, as a girl, did not own shoes that allow you to walk very far." Gevinson then comments how she wanted Rookie's feminism to be "accessible" and the difficulties in doing so "without watering it down" (Zeisler 2013). Here Gevinson calls attention to the ways in which gender inequalities, including access to public space, continue to restrict many girls' lives and 
opportunities, linking this reality to the need to discuss feminism in an accessible way on the site.

A posting by Gevinson about the Philadelphia stop on the Rookie road trip Tumblr illustrates the ways in which the Rookie meet-ups defy easy categorization; they are both productive and consumptive, political and personal, lighthearted and serious-minded. She writes, "After shopping we headed over the Rittenshouse Square Park to listen to the records we bought (Violent Femmes was on at full blast) and make pennant banners out of fabric. We had an interesting group chat about feminism and its place in fashion and we also tackled tricky questions such as "Clueless vs. Heathers vs. Mean Girls: which is the best?" (Gevinson 2012a). Gevinson's post points to the ways in which the Rookie meet-up functioned as creating public space for girls to come together and talk, engage in cultural production, and form friendships. While the meet-ups are not explicitly framed as "political" or "feminist," feminist politics are nonetheless part of the conversations that occur. We can contextualize the Rookie road tip as part of a lengthy history of girls and women coming together to share their experiences, including woman liberationists' consciousness raising circles and riot grrrls' meetings and conventions.

While Rookie readers were no doubt excited to meet Gevinson herself, the tour also functioned as a way for "Rookies" to connect with one another. Gevinson emphasizes this in her final tour diary entry where she instructs girls to organize their own Rookie meet-ups in their respective towns, prescribing these potential friendships as a way to generate "a little less sadness in one corner of the world" 
(Gevinson 2012b). Thus, Gevinson recognizes the power of female friendships to minimize negative affects, or "sadness," in girls' lives. In doing so Gevinson presents an alternative to postfeminist narratives of girls' friendships that assume girls as catty, competitive, and untrustworthy (Ringrose 2012), and uses media production to make girls' friendships not only publicly visible, but necessary for countering neoliberal girlfriend culture (Winch 2013).

\section{Conclusions: The Self-Brand and Contemporary Feminism}

In this paper I have demonstrated how, through her creation of Rookie Magazine, Gevinson has successfully created discursive and physical space within postfeminist media culture for a thriving feminist girls' culture. Drawing on the feminist ideas and practices of the riot grrrls, Gevinson has publicly emphasized the importance of feminism for girls and introduced her readers to both feminist politics and the history of those politics - a notable accomplishment within a media culture where feminism occupies an ambiguous status. In doing so, Gevinson challenges key aspects of postfeminist femininity, such as the belief that girls are apolitical and the reliance on the trope of the mean girl to understand girls' friendships. This analysis thus suggests the need for feminist media scholars to move beyond merely identifying postfeminist discourses within media culture and instead examine the complex ways in which feminist politics "poke holes" in an often seemingly daunting and oppressive media culture. This is crucial for scholars interested in girls' media cultures, as there continues to be a dearth of girls' studies scholarship that 
recognizes the political agency of girls, particularly within the context of online media (Caron 2011; Keller 2013).

Nonetheless, I have also argued that Gevinson's success in creating Rookie is due, in part, to the currency of her self-brand as one of the stylish, smart, and culturally-savvy feminist. While it is inspiring and exciting to see young feminists gain public attention - which may point to a resurgence of feminism within mainstream media culture - I am suggesting that we must be critical of the ways in which self-branding remains about individual image. Thus, Gevinson's performance of a feminist identity becomes associated with her privileged subject position informed by whiteness, upper-middle classness, American-ness, and ultimately, high subcultural capital that grants her the opportunities to befriend Kathleen Hanna, enter into a promotional relationship with Urban Outfitters and generate income and celebrity status. This raises significant questions about the ability for feminism to function as a "brand" while maintaining focus as a collective movement - a debate that has been recently taken up in the feminist blogosphere.

To wit: in an October 2013 article in the Daily Beast Ana Cecilia Alvarez argues that the "decidedly hip" style of feminism circulating on blogs like Jezebel and hawked in their new coffee table tome The Book of Jezebel represent a narrow approach to feminism that often function to bolster the image of those who consume these media products. She argues, "All that a feminist brand induces is an impulse to buy. But the feminism worth fighting for won't be listed in an encyclopedia of lady 'things' - it evades such simplicity...and must be approached with intersectional and anti-oppression frameworks in mind." Thus, we must understand the success of 
Gevinson's brand, including Rookie, as a product of this same postfeminist media culture, where girls and women are required to self-brand as a strategy by which they may take part in public life. Feminism, as we've seen with Gevinson, can increase the value of one's brand if performed in a way that is read as "hip" and avoids threatening the consumer logic of the capitalist marketplace. We must be mindful of how these discourses function to interpellate certain girls and women as feminist subjects, while leaving the experiences of others outside of the popular articulations of feminism that may be found in publications like Rookie, Jezebel, and initiatives like \#ElleFeminism.

While girls' studies scholars have been rightly critical of the figure of the girl entrepreneur (Harris 2004; Banet-Weiser 2012) it is important to remember that she is not only a product of neoliberal postfeminist media culture, but also of feminism itself. Indeed, it wasn't long ago when it would be absurd to think about a teenage girl running a successful magazine. In this sense, girls like Gevinson make visible the accomplishments of (liberal) feminism and demonstrate that a feminist "girl power" may have a renewed tenacity within postfeminist media culture.

\section{Acknowledgements}

I'd like to thank Amy Dobson and Anita Harris for their guidance and suggestions for improving this paper. I'm also grateful for the helpful comments and encouragement from Morgan Blue, Jessica Ringrose, and Alison Harvey, who read early drafts of this article.

\section{References}

Alvarez, Ana Cecilia. 2013. "How is feminism branded?" The Daily Beast, October 21. http://www.thedailybeast.com/witw/articles/2013/10/21/the-book-ofjezebel-branding-feminism.html 
Banet-Weiser, Sarah. 2012. Authentic TM: The Politics of Ambivalence in a Brand Culture. New York: New York University Press.

Bastow, Clem. 2012. “The new riot grrrls?” Daily Life, June 5. http://www.dailylife.com.au/news-and-views/dl-opinion/the-new-riotgrrrls-20120604-1zrc9.html.

Bazillian, Emma. 2013. “16-Year Old Media Mogul is Expanding Her Empire, Including Online Mag Rookie." Adweek, April 14. http://www.adweek.com/news/advertising-branding/16-year-old-mediamogul-tavi-gevinson-expanding-her-empire-148565

Butler, Judith. 1990. Gender Trouble: Feminism and the Subversion of Identity. New York: Routledge.

Butler, Judith. 1993. Bodies That Matter: On the Discursive Limits of Sex. New York: Routledge.

Caron, Caroline. 2011. "Getting Girls and Teens in the Vocabularies of Citizenship." Girlhood Studies 4 (2): 70-91.

Currie, Dawn, Deirdre Kelly, and Shauna Pomerantz. 2009. 'Girl Power:' Girls Reinventing Girlhood. New York: Peter Lang.

Dobson, Amy. 2008. "Femininities as Commodities: Cam Girl Culture.” In Next Wave Cultures: Feminism, Subcultures, Activism, edited by Anita Harris, 123-148. New York: Routledge.

Gevinson, Tavi. 2011. "First Encounters with the Male Gaze." Rookie, September 28. http://rookiemag.com/2011/09/male-gaze/

Gevinson, Tavi. 2012a. "Philadelphia Road Trip." Rookie, June 2 http://rookiemag.tumblr.com.

Gevinson, Tavi. 2012b. “Road Trip Diary: Week Five.” July 30. http://www.rookiemag.com/2012/07/road-trip-diary-week-five/

Gill, Rosalind. 2007. "Postfeminist Media Culture: Elements of a Sensibility." European Journal of Cultural Studies 10 (2): 147-166.

Gonick, Marnina, Emma Renold, Jessica Ringrose, and Lisa Weems. 2009. "Rethinking Agency and Resistance." Girlhood Studies 2 (2): 1-9.

Goodman, Abbey. 2013. “Tavi Gevinson May Take Over the World While You Read 
This." CNN.com, January 2.

http://www.cnn.com/2013/01/02/showbiz/celebrity-news-gossip/tavigevinson-profile/

Hains, Rebecca. 2012. Growing Up With Girl Power: Girlhood on Screen and In Everyday Life. New York: Peter Lang.

Harris, Anita. 2004. Future Girl: Young Women in the Twenty-first Century. New York: Routledge.

Hearn, Alison. 2008. 'Meat, Mask, Burden:' Probing the Contours of the Branded Self." Journal of Consumer Culture 8 (2): 197-217.

Hearn, Alison. 2010. "Structuring Feeling: Web 2.0, Online Ranking and Rating, and the Digital 'Reputation Economy." Ephemera 10 (3/4): 421-438.

Hearn, Alison. 2012. "Brand Me 'Activist."' In Commodity Activism: Cultural Resistance in Neoliberal Times, edited by Roopali Mukherjee and Sarah BanetWeiser, 23-38. New York: New York University Press.

Hopkins, Susan. 2002. Girl Heroes: The New Force in Popular Culture. London: Pluto Press.

Jenkins, Henry. 2006. Convergence Culture: Where Old and New Media Collide. New York: New York University Press.

Kearney, Mary Celeste. 2006. Girls Make Media. New York: Routledge.

Keller, Jessalynn. 2012. Virtual Feminisms. Information, Communication and Society 15 (3): 429-447.

Keller, Jessalynn. 2013. ''Still Alive and Kicking:' Girl Bloggers and Feminist Politics in a Postfeminist Age." PhD diss, The University of Texas at Austin.

McRobbie, Angela. 2009. The Aftermath of Feminism: Gender, Culture and Social Change. Thousand Oaks: Sage.

Negra, Diane. 2009. What a Girl Wants? Fantasizing the Reclamation of Self in Postfeminism. New York: Routledge.

Onstad, Katrina. 2012. “Is Tavi Gevinson girl power's last chance?” The Globe and Mail, September 13. http://www.theglobeandmail.com/life/is-tavi-gevinsongirl-powers-last-chance/article4543738/

PBS. 2012. Makers Profile: Tavi Gevinson. http://www.makers.com/tavi-gevinson. 
Ringrose, Jessica. 2012. Postfeminist Education? Girls and the Sexual Politics of Schooling. London: Routledge.

Senft, Theresa. 2008. Camgirls: Celebrity and Community in the Age of Social Networks. New York: Peter Lang.

Schulmann, Michael. 2012. The Oracle of Girl World. The New York Times, July 27. http://www.nytimes.com/2012/07/29/fashion/tavi-gevinson-the-oracle-ofgirl-world.html

Thornton, Sarah. 1996. Club Cultures: Music, Media and Subcultural Capital. Middletown: Wesleyan University Press.

Wald, Gayle. 1997. "One of the Boys? Whiteness, Gender, and Popular Music Studies." In Whiteness: A Critical Reader, edited by Mike Hill, 151-167. New York: New York University Press.

Winch, Alison. 2013. Girlfriends and Postfeminist Sisterhood. London: Palgrave Macmillan.

Zaslow, Emilie. 2009. Feminism, Inc. Coming of Age in Girl Power Media Culture. New York: Palgrave MacMillan.

Zeisler, Andi. 2013. "An Interview with Rookie Editor Tavi Gevinson." Bitch Magazine, December 9. http://bitchmagazine.org/post/an-interview-withrookie-editor-tavi-gevinson.

${ }^{1}$ Despite being appropriated into commercial popular culture in the late 1990s, it is necessary to recognize the term "girl power" as originating within riot grrrl. I also want to emphasize the contested nature of riot grrrl as a movement that defies easy categorization and suggest that my analysis is not intended to be a comprehensive discussion of the subculture. 